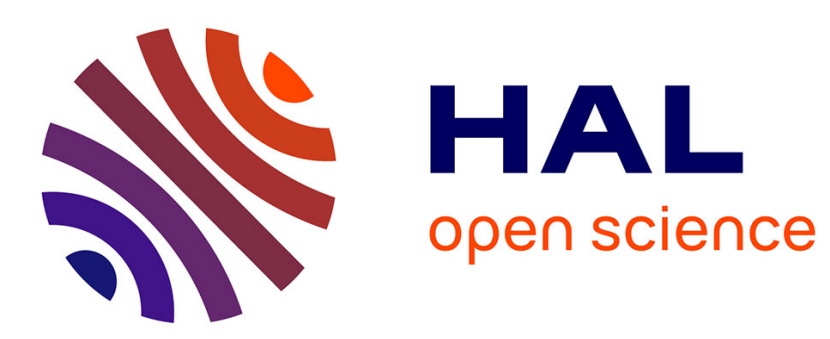

\title{
Local redox buffering by carbon at low pressures and the formation of moissanite - natural $\mathrm{SiC}$
}

\author{
Andrei A. Shiryaev, Fabrice Gaillard
}

\section{To cite this version:}

Andrei A. Shiryaev, Fabrice Gaillard. Local redox buffering by carbon at low pressures and the formation of moissanite - natural SiC. European Journal of Mineralogy, 2014, 26, pp.53-59. 10.1127/09351221/2013/0025-2339 . insu-00985690

\section{HAL Id: insu-00985690 https://hal-insu.archives-ouvertes.fr/insu-00985690}

Submitted on 17 May 2017

HAL is a multi-disciplinary open access archive for the deposit and dissemination of scientific research documents, whether they are published or not. The documents may come from teaching and research institutions in France or abroad, or from public or private research centers.
L'archive ouverte pluridisciplinaire HAL, est destinée au dépôt et à la diffusion de documents scientifiques de niveau recherche, publiés ou non, émanant des établissements d'enseignement et de recherche français ou étrangers, des laboratoires publics ou privés. 


\title{
Local redox buffering by carbon at low pressures and the formation of moissanite - natural SiC
}

\author{
ANDREI A. SHIRYAEV ${ }^{1,2, *}$ and FABRICE GAILLARD ${ }^{3}$ \\ ${ }^{1}$ Institute of Physical Chemistry and Electrochemistry RAS, Leninsky pr. 31, 119071 Moscow, Russia \\ ${ }^{2}$ Institute of Geology of Ore Deposits, Petrography, Mineralogy and Geochemistry RAS, Staromonetny per. 35, \\ 119017 Moscow, Russia \\ *Corresponding author, e-mails: shiryaev@phyche.ac.ru; a_shiryaev@mail.ru \\ ${ }^{3}$ CNRS/INSU, Institut des Sciences de la Terre d'Orléans - UMR 6113, Université d'Orléans, Campus Géosciences, \\ 1 A rue de la Férollerie, 41071 Orléans cedex 2, France
}

\begin{abstract}
Grains of natural SiC, moissanite, are encountered in various geological settings. According to thermodynamic calculations and high-pressure experiments, $\mathrm{SiC}$ formation requires very reducing conditions, approx. 6-10 orders of magnitude in $f \mathrm{O}_{2}$ more reducing than the present-day mantle redox state. $\mathrm{SiC}$ occurrences have motivated several studies but the required extremely reducing conditions remain a major inconsistency that has not been solved. It is shown here that such reducing conditions can be achieved during the ultimate steps of ascent of carbon-saturated melts, when pressure is lower than 100 bars. At these conditions, the redox buffering by carbon can impose $\mathrm{fO}_{2}$ similar to IW-6. Conditions favorable to SiC growth can therefore be reached around carbonaceous grains during the shallow emplacement of silicate melts or kimberlites and do not necessarily imply extremely localized oxygen-depleted regions in the mantle. Such reduced conditions can also explain the presence of elemental Si and ironcarbide inclusions in association with moissanite grains.
\end{abstract}

Key-words: moissanite, silicon carbide, carboreduction, mantle redox state, thermodynamic modeling.

\section{Introduction}

\subsection{Mantle redox state}

The evolution of mantle redox state and its heterogeneities are matter of a long standing debate (Frost \& McCammon, 2008). The generally accepted picture is that most mantle rocks, including basaltic melts, are equilibrated at oxygen fugacity in the range FMQ-2 to FMQ + 0.5, expressed as log-unit relative to FMQ, the fayalite-magnetite-quartz redox buffer (Behrens \& Gaillard, 2006; Frost \& McCammon, 2008), and these conditions have been established probably 3.9 Ga ago (Canil, 2002). More reducing conditions - down to FMQ-4 (Woodland \& Koch, 2003; McCammon \& Kopylova, 2004) may be locally preserved, e.g. underneath cratons, as indicated by mantle xenoliths. This is suggested by experimental constraints indicating deep lithospheric roots and some regions of the asthenosphere being saturated in Fe-metal (Rohrbach et al., 2007). It would imply lowermost $f \mathrm{O}_{2}$ values at FMQ-6 (i.e. IW-1.5, where IW stands for the iron-wüstite redox buffer), but recent experimental recalibrations of redox equilibria in garnet peridotites (Stagno et al., 2013) suggest that the FMQ- 4 should rather be the lowermost $\mathrm{fO}_{2}$ values for the upper mantle. It is therefore accepted that oxygen fugacity is decreasing with increasing depth in the upper mantle, but the magnitude of this effect seems to be moderate, remaining close to, but still definitively above the saturation in Fe-metal.

\subsection{Moissanite occurrences}

The redox conditions prevailing in the upper parts of the Earth mantle and crust make difficult the explanation of numerous findings of natural silicon carbide - moissanite in very different geological settings (for reviews on $\mathrm{SiC}$ occurrences see, e.g. Kaminsky et al., 1968; Derkachenko et al., 1972; Lyakhovich, 1979; Marshintsev, 1990). Moissanite has been found as inclusions in diamonds (Jaques et al., 1989; Moore \& Gurney, 1989; Leung et al., 1990; Klein-BenDavid et al., 2007), in mantlederived magmatic rocks such as kimberlites (Bobrievich et al., 1957; Shiryaev et al., 2011), picritic traps (Kitaynik, 1958; Oleinikov et al., 1977; Iacono-Marziano et al., 2012b) and volcanic breccias (Bauer et al., 1963; Gorshkov et al., 1995; Di Pierro et al., 2003, and many others). More enigmatic occurrences include high- and low-grade metamorphic rocks, limestones, pegmatites and chromitite pods within ophiolites (Gnoevaja \& Grozdanov, 1965; Lyakhovich, 1967, 1979; Marshintsev, 
1990 and references therein; Miyano et al., 1982; Shiryaev et al., 2008; Trumbull et al., 2009). An association of moissanite in serpentinite from ultrahigh-pressure (UHP) metamorphic rocks was described by Xu et al. (2008).

Information about moissanite petrological environment is limited, since the majority of finds are related to separate grains recovered from heavy fractions. In Si-rich rocks moissanite is sometimes found as intergrowth with quartz and alkali feldspars (Mineyeva \& Kartenko, 1967; Leung et al., 1990). Intergrowth with quartz possibly results from partial oxidation of $\mathrm{SiC}$ and cannot really be used as a reliable criterion of syngenetic origin. Di Pierro et al. (2003) observed unidentified $\mathrm{MgFe}$-silicates with $\mathrm{FeO}$ contents ranging between 3 and 8 wt $\%$ in contact with $\mathrm{SiC}$. Moissanite from kimberlites is sometimes in association with calcite and chromite (Marshintsev, 1990). It was also observed in magnetite-olivine breccia in carbonatitic rocks (Glushkina et al., 1963). In summary, investigation of a large number of moissanite occurrences shows absence of preferred mineral phases associated with $\mathrm{SiC}$.

Diamonds and kimberlites are important rocks in the discussion of moissanite occurrences. Indeed, the first reliable observation of natural moissanite was made in kimberlite (Bobrievich et al., 1957). Subsequently, rare moissanite inclusions in natural diamonds were discovered, in association with eclogitic garnet, peridotitic diopside, rutile, kappa-alumina, sanidine plus andradite (Moore \& Gurney, 1989; Leung et al., 1990; Klein-BenDavid et al., 2007). A semi-amorphous K-Al-Si phase was observed in coexistence with moissanite both in diamonds (Leung et al., 1996) and as inclusion in SiC (Shiryaev et al., 2011). However, it is critically important to emphasise that $\mathrm{SiC}$ inclusions in diamonds are extremely rare (approx. 10 inclusions in total) in comparison with worldwide inventory of reliable moissanite discoveries and, therefore, attempts to relate moissanite exclusively to deep mantle are barely reasonable.

A recent detailed study of inclusions and trace elements of natural SiC (Shiryaev et al., 2011) shows that trace elements readily discriminate natural from synthetic SiC. Remarkably, trace elements in moissanite grains from various Siberian kimberlites and from Bulgarian limestones are broadly similar (Shiryaev et al., 2008). Grains of natural $\mathrm{SiC}$ of various origin often contain inclusions of highly reduced phases such as native $\mathrm{Si}$ (Marshintsev, 1990) and $\mathrm{Fe}-, \mathrm{Mg}-$, Ti-, Cr-silicides (Marshintsev, 1990; Di Pierro et al., 2003; Marshintsev et al., 1967; Mathez et al., 1995), which imply formation under extremely reducing conditions, well below the IW buffer that is commonly regarded as a lower limit in mantle $\mathrm{fO}_{2}$. This requires a mechanism for drastically lowering the $f \mathrm{O}_{2}$, at least locally.

The temperature of the moissanite formation might be bounded from observations of $\mathrm{FeSi}_{2}$ exsolved from $\mathrm{Si}$ inclusion in $\mathrm{SiC}$ as reported by Shiryaev et al. (2011). According to the low-pressure phase diagram (Kubaschewski, 1982), such exsolution occurs at temperatures lower than $937^{\circ} \mathrm{C}$. Therefore, one may expect that moissanite formation or at least nucleation took place in relatively hot environments.

\subsection{How to make $\mathrm{SiC}$, brief review of materials and Earth sciences}

Published experiments show that silicon carbide can be formed in very different ways (e.g., Knippenberg, 1963; Derkachenko et al., 1972), thus suggesting that moissanite can be a polygenic mineral. Models of moissanite formation can be roughly divided into those favoring "high" or "low" pressures.

The "high"-pressure models are largely centered on moissanite inclusions in diamonds and from kimberlites and imply existence of extremely reduced mantle volumes that contrast with the average mantle redox state (e.g., Di Pierro et al., 2003; Trumbull et al., 2009). However, the presence of such mantle domains is still debatable and the $\mathrm{H} T-\mathrm{H} P$ processes triggering moissanite formation in the lower mantle remain unspecified. Recently Bali et al. (2013) suggested that water $\left(\mathrm{H}_{2} \mathrm{O}\right)$ and hydrogen $\left(\mathrm{H}_{2}\right)$ can be immiscible at mantle pressure, implying coexistence of $\mathrm{H}_{2}$-rich and water-rich fluids. Even if $\mathrm{H}_{2}$ is a reducing agent, immiscibility is an equilibrium process, implying that oxygen fugacity of these immiscible fluids must be similar. So $\mathrm{H}_{2}$-rich fluid is not necessarily a solution for making $\mathrm{SiC}$ at mantle pressures as one still needs to trigger extremely reducing conditions (see Section 1.4).

The "low"-pressure models include moissanite formation by serpentinisation (Mathez et al., 1995) and electrochemical synthesis in carbonate-silicate melts (Shiryaev et al., 2011). The serpentinisation mechanism might have been important for moissanite inclusions found in metamorphic serpentine (Xu et al., 2008). The electrochemical route is based on material-sciences experiments in which growth of SiC layers was achieved during electrochemical reactions in carbonate-silicate melts. Whereas this scenario is feasible for some occurrences, it is difficult to extend it to all moissanite finds.

On the basis of observation of relatively high moissanite concentration at contacts between carbonates and magmatic rocks, Mineyeva \& Kartenko (1967) have suggested that moissanite is formed during emplacement of hot silicic melts into organics-rich carbonates. This scenario also explains isotopically light carbon common for moissanites. Similar interaction between low-pressure magma and carbonaceous matter was modelled by Iacono-Marziano et al. (2012b) to explain the formation of intrusive rocks rich in reduced Fe-metal and containing small amount of $\mathrm{SiC}$ (Ryabov \& Lapkovsky, 2010). In fact, carboreduction of silica at high temperatures with formation of $\mathrm{SiC}$ is a wellknown phenomenon, being the base of Acheson process of industrial production of $\mathrm{SiC}$ for abrasives. The industrial Acheson process is usually realised at very high temperatures exceeding $2000{ }^{\circ} \mathrm{C}$ (e.g., Knippenberg, 1963). However, numerous experiments have shown that $\mathrm{SiC}$ can be produced via gas-phase reactions between $\mathrm{SiO}_{2}$ and graphite (e.g., Blumenthal et al., 1966; Klinger et al., 1966) or various clays with graphite (Mazzoni et al., 1992; Mazzoni \& Aglietti, 1997a, 1997b) at temperatures as low as $1300{ }^{\circ} \mathrm{C}$. $\mathrm{SiC}$ formation is favored at high silica contents and low temperatures. Iron and possibly other metals may catalyse 
the reaction (Lee \& Cutler, 1975). An experimental synthesis of $\mathrm{SiC}$ by reaction of $\mathrm{SiO}_{2}+\mathrm{Na}_{2} \mathrm{CO}_{3}+\mathrm{C}$ (Blumenthal et al., 1966 ) is relevant to the suggestion of Mineyeva \& Kartenko (1967) and shows that, in case of molten silicates, the reaction is very fast during initial stages, but slows down rapidly when individual carbon particles are consumed.

\subsection{Required redox conditions for $\mathrm{SiC}$}

Despite a significant number of reliable reports of moissanite finds in many types of rocks, the fact that $\mathrm{SiC}$ formation requires extremely reducing conditions has fueled skepticism about most papers, with the exception of occurrences of moissanite and other reduced mineral suites in kimberlites. At equilibrium $\mathrm{SiC}$ can coexist with silicates only under conditions so reducing that their mantle origin has been questioned. The disruption of $\mathrm{Si}-\mathrm{O}$ bonds to form $\mathrm{Si}-\mathrm{C}$ ones indeed requires extremely oxygen-depleted environments. Thermodynamic calculations using the following equilibrium allows the $f \mathrm{O}_{2}$ defining the coexistence of moissanite and mantle minerals to be estimated:

$\mathrm{SiC}+\mathrm{Mg}_{2} \mathrm{SiO}_{4}+\mathrm{O}_{2}=2 \mathrm{MgSiO}_{3}+\mathrm{C}$.

Mathez et al. (1995) obtained oxygen fugacities that are 4 to $6 \log$ units below IW buffer (IW being approx. FMQ-4) for calculations performed over a range of pressure-temperature conditions of 2-18 GPa and 1000-1800 K. Highpressure experiments by Ulmer et al. (1998) support predictions by Mathez et al. (1995).

In summary, oxygen-depleted conditions required for $\mathrm{SiC}$ stability are difficult to reconcile with the mantle redox state. At equilibrium, $\mathrm{SiC}$ may coexist only with $\mathrm{Fe}$-free silicates (olivine, orthopyroxene and garnet), i.e. in assemblages similar to enstatite chondrites and those have never been observed in the Earth's mantle. The SiC grains have therefore never been equilibrated with the coexisting $\mathrm{Fe}-\mathrm{Mg}$ minerals even at hand-specimen scales. It must then reflect extremely local processes that never extended their equilibrium sphere to more than a couple of millimeters. In addition, the general paucity of oxidation products such as $\mathrm{SiO}_{2}$ or silicon oxycarbides on the surface of moissanite grains (for review of $\mathrm{SiC}$ oxidation see Presser \& Nickel, 2008) indicates that after their formation, the process of $\mathrm{SiC}$ grain re-equilibration with the surrounding phases was initiated only rarely. Therefore, a very important statement can be made here: the process responsible for formation of most moissanite grains must occur prior to the thermal quenching of the rocks, i.e. during the eruption/emplacement, in order to preserve such disequilibrium features.

In this report we provide results of thermodynamic calculations, giving support for a moissanite formation in very different geological settings by a process similar to the industrial Acheson process: $3 \mathrm{C}+\mathrm{SiO}_{2}=\mathrm{SiC}+2 \mathrm{CO}$. We show that $\mathrm{SiC}$ formation can occur during the ultimate steps of ascent of degassing, C-saturated silicate rocks or melts, when pressure is lower than 100 bars. At these conditions, the redox buffering by carbon can locally impose $f \mathrm{O}_{2}$ similar to IW-6, thus making $\mathrm{SiC}$ formation possible.

\section{Methods and results}

\subsection{Thermodynamic model}

We first model the oxygen fugacity imposed by carbon-gas equilibria at low pressures ( $3 \mathrm{kbar}$ to $1 \mathrm{bar}$ ) in the $\mathrm{C}-\mathrm{O}$ system. We assumed temperature of $1300{ }^{\circ} \mathrm{C}$, a temperature sufficient to produce synthetic $\mathrm{SiC}$ in experiments and not uncommon for some (e.g., picritic) magmas (e.g., Herzberg et al., 2010, and references therein). Note that moissanite was indeed observed in picritic traps (e.g., Kitaynik, 1958; Oleinikov et al., 1977). The computed equilibria are:

$\mathrm{C}+\mathrm{O}_{2}=\mathrm{CO}_{2}$

which gives

$f \mathrm{O}_{2}=f \mathrm{CO}_{2} / \mathrm{K}_{(2)}$

and

$\mathrm{C}+1 / 2 \mathrm{O}_{2}=\mathrm{CO}$

which gives

$f \mathrm{O}_{2}=f \mathrm{CO}_{2} / \mathrm{K}_{(4)}$.

In all cases, $\mathrm{K}_{\mathrm{x})}$ refers to the thermodynamic constant of the equilibrium (X) (see compilation in Symonds \& Red, 1993, for the thermodynamic constants) and " $f$ " refers to the fugacity of gas species (see Shi \& Saxena, 1992, for a complete description). In a recent analysis of gas-melt equilibria at temperaturepressure conditions equivalent to $1200-1400{ }^{\circ} \mathrm{C}$, 1 bar-10 kbar, Iacono-Marziano et al. (2012a) have concluded that gas species $\left(\mathrm{CO}_{2}-\mathrm{H}_{2} \mathrm{O}\right)$ must behave as an ideal mixture of ideal gases. For our calculation at $P<3 \mathrm{kbar}$ and $T=1300{ }^{\circ} \mathrm{C}$, we therefore simplified our fluid system as an ideal mixture of ideal gases (i.e. fugacities are equivalent to partial pressures). Combining (3) and (4) with the constraints that the partial pressures of the gas compounds sum to the total pressure,

$P\left(\mathrm{CO}_{2}\right)+P(\mathrm{CO})=P_{\text {tot }}$

we obtained that $f \mathrm{O}_{2}$-pressure relationships must follow the equation:

$f \mathrm{O}_{2}-\mathrm{K}_{(4)} / \mathrm{K}_{(2)} f \mathrm{O}^{1 / 2}=P_{t o \mathrm{t}} / \mathrm{K}_{(2)}$.

The resolution of equation (7) as a function of pressure results in the plot shown in Fig. 1a. Due to the strong decrease in $\mathrm{CO}_{2}$ partial pressure, $P\left(\mathrm{CO}_{2}\right)$, with decreasing pressure, equilibria (2) and (4) are shifted to the right and oxygen fugacity at graphite saturation decreases nearly proportionally to total pressure.

The second calculation considers a system gas-meltgraphite with the stable volatile species in a $\mathrm{C}-\mathrm{O}-\mathrm{H}$ system (see Gaillard \& Scaillet, 2009, for details of gas-melt equilibria, Fig. 1b). In that case, equilibrium (2) and (4) are treated together with the reaction of water dissociation and methane formation:

$\mathrm{H}_{2} \mathrm{O}=\mathrm{H}_{2}+1 / 2 \mathrm{O}_{2}$ 


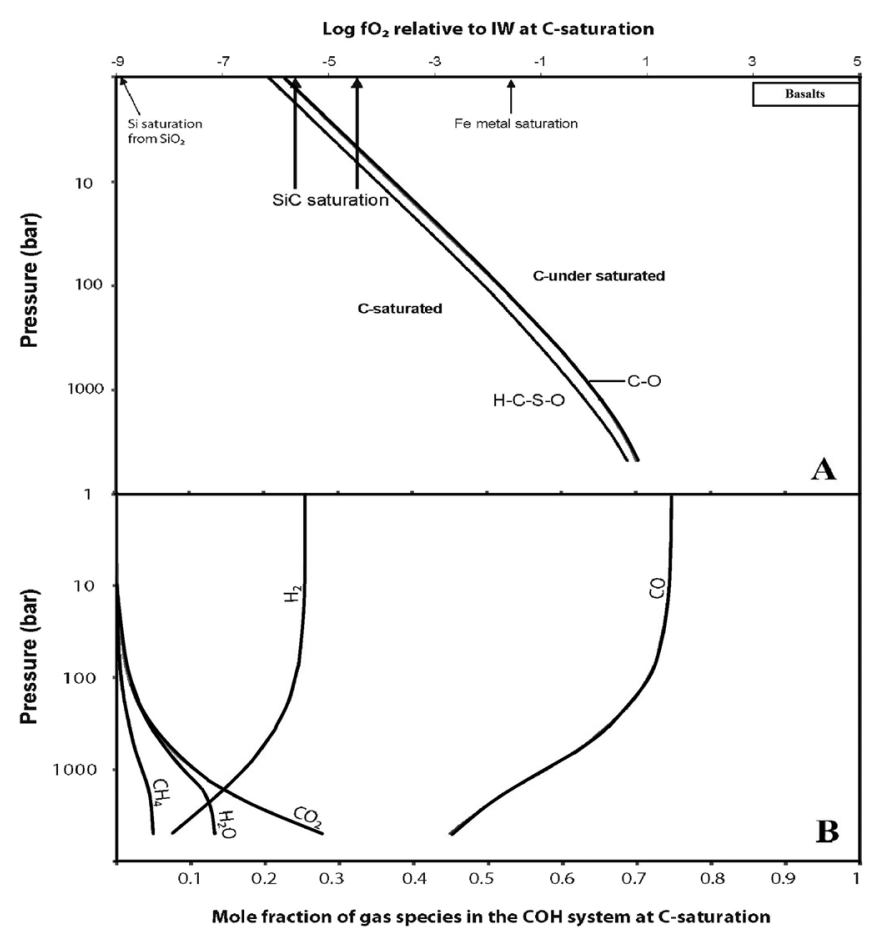

Fig. 1. (a) Oxygen fugacity of the Earth mantle and its incompatibility with $\mathrm{SiC}$ stability. The recognized $f \mathrm{O}_{2}$ range of the upper and lower mantle is shown as lower-bounded by Fe-metal saturation curve (IW-2, $\mathrm{fO}_{2}$ relative to the iron-wüstite, IW, redox buffer). At $f \mathrm{O}_{2}$ more reducing than IW-2, iron of the silicate phases is reduced, which represents a redox boundary through which the Earth mantle is not passing. The $f \mathrm{O}_{2}$ domain of $\mathrm{SiC}$ stability is simplified as a vertical grey arrow around IW-5. SiC stability requires $f \mathrm{O}_{2}$ more reducing than this value. The changes in oxygen fugacity undergone by a system buffered by carbon-saturation at $1300{ }^{\circ} \mathrm{C}$ is shown as a function of pressure. Two curves are shown, the $\mathrm{C}-\mathrm{O}$ one represents graphite-gas equilibrium in the $\mathrm{C}-\mathrm{O}$ system (with $\mathrm{CO}$ and $\mathrm{CO}_{2}$ species fraction in the gas shown in the inset). The $\mathrm{H}-\mathrm{C}-\mathrm{S}-\mathrm{O}$ curve shows the $f \mathrm{O}_{2}$-pressure path of a graphite-saturated magma that contained 3 wt $\% \mathrm{CO}_{2}$ and $3 \mathrm{wt} \% \mathrm{H}_{2} \mathrm{O}$. The $\mathrm{H}-\mathrm{C}-\mathrm{S}-\mathrm{O}$ curve therefore illustrates a 3-phase system: graphite-melt-gas computed using Gaillard et al. (2003) procedure. A more detailed picture is provided in Fig. 1b. Despite the difference in both calculations, the results are similar, highlighting the dominant role of carbon-redox buffering in both cases. At pressure lower than 100 bars, metal iron can precipitate and, at surface pressure, $\mathrm{SiC}$ should form by equilibration between olivine and carbon. (b) Changes in gas composition and $\mathrm{fO}_{2}$ during depressurisation of carbon-saturated magma. As pressure decreases, equilibrium $\mathrm{H}_{2} \mathrm{O}$ and $\mathrm{CO}_{2}$ abundances decrease to zero and $\mathrm{H}_{2}$ and $\mathrm{CO}$ become dominant. As a result, $\mathrm{fO}_{2}$ drops to value more reducing than IW-6, which should allow $\mathrm{SiC}$ saturation during the low-pressure step.

$\mathrm{C}+2 \mathrm{H}_{2}=\mathrm{CH}_{4}$.

The equilibrium constant for these reactions can be found in Symonds \& Red (1993). Due to the increase in the chemical complexity of the system, equation (6) becomes:

$$
\begin{aligned}
& P\left(\mathrm{CO}_{2}\right)+P(\mathrm{CO})+P\left(\mathrm{CH}_{4}\right)+P\left(\mathrm{H}_{2} \mathrm{O}\right)+P\left(\mathrm{H}_{2}\right) \\
& \quad=P_{\text {tot }} .
\end{aligned}
$$

The melt considered is basaltic in composition. Gas-melt equilibrium for $\mathrm{CO}_{2}-\mathrm{H}_{2} \mathrm{O}$ is taken from Iacono-Marziano et al. (2012a); $\mathrm{H}_{2}$ solubility is taken from Gaillard et al. (2003) and other species are considered as insoluble in the melt at these $P-T$ conditions (Morizet et al., 2010). The implementation of gas-melt equilibria with graphite-redox equilibrium (eq. 2 and 4 ) is described in detail in IaconoMarziano et al. (2012b). The amount of $\mathrm{H}_{2} \mathrm{O}$ and $\mathrm{CO}_{2}$ in the system is $3 \mathrm{wt} \%$ for both species. The amount of graphite and the amount of gas calculated as a function of pressure is shown in Fig. 2. During the entire decompression, the gas-melt system remains graphite saturated (graphite content at $300 \mathrm{MPa}$ is $3.5 \mathrm{wt} \%$ and gas percentage is $3.2 \mathrm{wt} \%$ ). The $\mathrm{fO}_{2}$ pressure evolution of such a system does not differ much from that occurring in a simple $\mathrm{C}-\mathrm{O}$ system. Figure 1a shows that $f_{2}$ is slightly more reduced essentially as a consequence of a dilution effect: $\mathrm{CO}$ and $\mathrm{CO}_{2}$ are diluted by $\mathrm{CH}_{4}, \mathrm{H}_{2} \mathrm{O}$ and $\mathrm{H}_{2}$, which shift equilibria (2) and (4) to the right-hand side.

In summary, the trends shown in Fig. 1 reflect the redox buffering by carbon-saturated systems upon decompression. This picture remains true whatever the phase coexisting with carbon (gas, melt, solids) provided that carbon is buffering $\mathrm{fO}_{2}$. Note that Sato (1978) already mentioned the possibility of such buffering effect of carbon on magma redox state with application to the Moon (see also Nicholis \& Rutherford, 2009 on a similar topic).

The calculations shown in Fig. 1 were performed for a temperature of $1300{ }^{\circ} \mathrm{C}$, which is based on experimental works on $\mathrm{SiC}$ formation by carboreduction process and on moissanite observations in picritic rocks. It is important to note that carboreduction is a viable mechanism for $\mathrm{SiC}$ formation even at lower temperatures, as shown on Fig. 3, if the pressure is low enough. However, kinetics of $\mathrm{SiC}$ formation may be very slow at temperatures as low as $1100{ }^{\circ} \mathrm{C}$, thus making moissanite formation less likely.

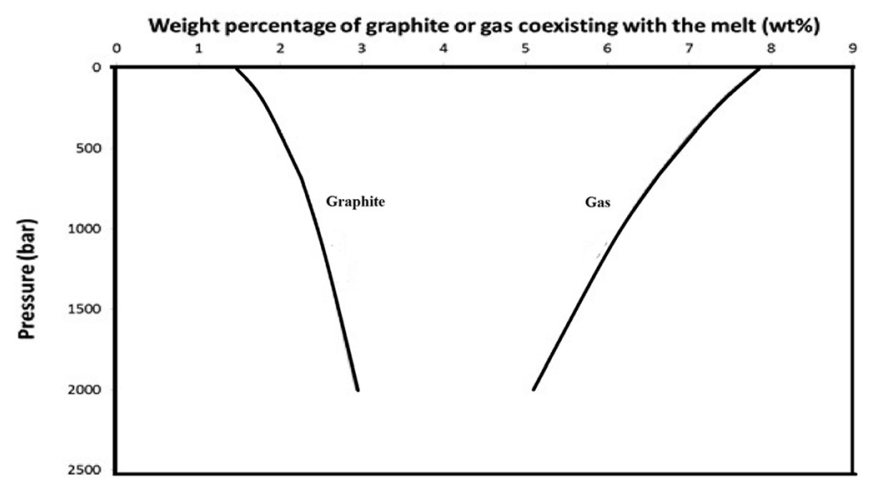

Fig. 2. Calculated mass percentage of graphite and gas during decompression. The initial water and $\mathrm{CO}_{2}$ contents (both fixed at 3 $\mathrm{wt} \%$ ) were chosen in order to mirror concentrations reconstructed by Kopylova et al. (2007) for kimberlite parental magmas. These high volatile contents also maximize the dilution effect and its impact on $\mathrm{fO}_{2}$ discussed in the text. With depressurization of the graphite-meltgas system, graphite volatilizes as $\mathrm{CO}$ (see Fig. $1 \mathrm{~b}$ for $\mathrm{CO}$ production in the gas). Therefore the fraction of graphite decreases and the mass percentage of gas increases well outside the $3 \mathrm{wt} \% \mathrm{CO}_{2}+3 \mathrm{wt} \%$ $\mathrm{H}_{2} \mathrm{O}$ because of $\mathrm{C}$ volatilization as $\mathrm{CO}$. 


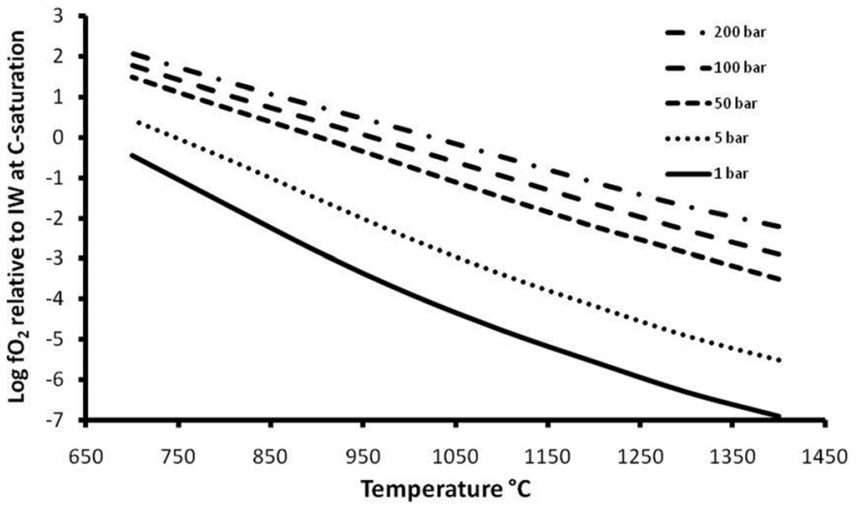

Fig. 3. The effect of temperature on the $\mathrm{fO}_{2}$ at graphite saturation of a magmatic system.

At surface pressures, oxygen fugacity reaches values similar to IW-6, which are required to precipitate $\mathrm{SiC}$ from silica-bearing minerals such as olivine that coexists with carbon (Figs. 1b and 3). Fe-metal can precipitate at $\mathrm{fO}_{2}$ lower than IW-2 (Gaillard \& Scaillet, 2009), which is possible when pressure is lower than 100 bars (see IaconoMarziano et al., 2012b, for additional simulation). Lowpressure local redox buffering by carbon is a likely explanation for the presence of reduced species in igneous rocks that do not require extremely reduced mantle regions, which are otherwise unexpected. Depending on the amount of carbon in the rock, the carbon buffering can be local or global. The Disko Island and the Siberian Traps cases illustrated in Iacono-Marziano et al. (2012b) correspond to a global C-buffering that affects large volumes of magma (intrusion of basalts into coal-rich sediments). In the case of small amount of graphite, C-redox buffering is affecting only the narrow vicinity of carbon-bearing phases and is not imposing a redox change of the entire rock. Temperature changes are expected to moderately affect the redox trend of Fig. 1a. The decrease in oxygen with decreasing pressure will become more pronounced as $\mathrm{CH}_{4}$ will increasingly be stable. The fraction of both gaseous $\mathrm{CO}$ and $\mathrm{CO}_{2}$ will then be decreased which implies slightly lower $f_{2}$ at graphite saturation.

\subsection{Formation of moissanite at $\mathrm{C}$-saturation}

At low pressures in system with redox conditions controlled by carbon-buffering, $\mathrm{SiC}$ can easily be formed as $\mathrm{fO}_{2}$ are lower than IW-4. This process is moderately affected by temperature and can operate in solids or melts coexisting with carbon. What is needed is a source of silicon at carbon-saturation under low pressures $(<20$ bars). Silica activity must then play a role in stabilizing $\mathrm{SiC}$. Equilibrium (1) indicates that in addition to low $\mathrm{fO}_{2}$, $\mathrm{SiC}$ formation is favored by elevated silica activities. The association of $\mathrm{SiC}$ with carbonated melts (Glushkina et al., 1963; Gnoevaja \& Grozdanov, 1965; Shiryaev et al., 2011) that are well-known for their low silica activity (Luth, 2009), may then seem surprising. Furthermore, as reviewed in Section 1.2., no typical mineral association is preferentially found with SiC. Silicate minerals, carbonates or oxides have been found so that no general reaction mechanisms can be proposed.

The most generic reaction forming $\mathrm{SiC}$ could be:

$$
\begin{aligned}
6 \mathrm{C}+4 \mathrm{MgSiO}_{3} \rightarrow & 2 \mathrm{SiC}+6 \mathrm{CO} \\
& +2 \mathrm{Mg}_{2} \mathrm{SiO}_{4}
\end{aligned}
$$

as olivine and pyroxene are present in many SiC-bearing rocks. It is known that excessive partial pressure of $\mathrm{CO}$ suppresses silicate reduction in this process, which is qualitatively similar to the Acheson one (Derkachenko et al., 1972). Therefore, a requirement for this process to generate appreciable quantities of $\mathrm{SiC}$ is that the produced $\mathrm{CO}$ is evacuated from the local system. Permeability of rocks and melts in respect to $\mathrm{CO}$ gas or high $\mathrm{CO}$ solubility in them should, therefore, play an important role for moissanite formation. Permeability of extrusive rocks during emplacements at surface is usually elevated enough to ensure gas removal. This feature is enhanced by high volatile contents.

On the other hand, if reaction (11) can be justified as olivine and pyroxene are abundant in SiC-bearing rocks, $\mathrm{Fe}$-free forsterite is never found in coexistence with $\mathrm{SiC}$. Given the absence of systematic mineral association with $\mathrm{SiC}$, we could suggest a gas-phase reaction such as:

$\mathrm{SiO}^{\text {gas }}+2 \mathrm{C}=\mathrm{SiC}+\mathrm{CO}^{\text {gas }}$

This mechanism has the great advantage of leaving no systematic or typical mineralogical assemblages associated with $\mathrm{SiC}$ as recognized in Section 1.2. We discuss below relationships previously recognized between $\mathrm{SiO}$ and $\mathrm{SiC}$ formation.

\subsection{Formation of highly reduced phases together with moissanite}

As mentioned in the Introduction, moissanite is often accompanied by inclusions of highly reduced phases such as elemental silicon, various carbides and silicides. Reduction of $\mathrm{SiO}_{2}$ to $\mathrm{Si}$-metal requires extremely low values of $f \mathrm{O}_{2}$, which can not be attained considering carbon redox buffering $\left(f \mathrm{O}_{2}<\mathrm{IW}-9\right.$ considering $\left.a\left(\mathrm{SiO}_{2}\right)=1\right)$. However, formation of Si-metal from gaseous $\mathrm{SiO}$ (see reaction below) is feasible at $f \mathrm{O}_{2}$ lower than IW-4 if silicon-monoxide activity $a(\mathrm{SiO})$ is close to unity:

$\mathrm{SiO}^{\text {gas }}=\mathrm{Si}^{\text {solid }}+1 / 2 \mathrm{O}_{2}$.

The $f \mathrm{O}_{2}$ corresponding to the above equilibrium is within the range of $f \mathrm{O}_{2}$ imposed by carbon-saturation at low pressure (Fig. 1). It is therefore possible that graphite saturation at low pressure generates $\mathrm{SiC}$ together with $\mathrm{Si}$ and $\mathrm{Si}-\mathrm{Fe}$ metal grains. This demands high $\mathrm{SiO}$ activities. According to kinetics experiments (Mendybaev et al., 2002), redox conditions favorable to $\mathrm{SiC}$ growth also favors vaporization of silicate in $\mathrm{SiO}$ form at 1 bar pressure in atmosphere composed of $\mathrm{H}-\mathrm{C}-\mathrm{O}$ species. At magmatic temperatures $\left(1300^{\circ} \mathrm{C}\right)$ and $f \mathrm{O}_{2}$ in the range IW- 3 to IW-6, $\mathrm{SiO}$ can constitute a significant 
fraction of the gas (at $\mathrm{SiO}_{2}$ saturation) (Mendybaev et al., 2002). We can therefore not exclude that Si grains result from local equilibrium processes imposing high $\mathrm{SiO}$ activities. Similarly to $\mathrm{SiC}$ grains that are clearly not equilibrated with the surrounding Fe-bearing silicates, in terms of $f \mathrm{O}_{2}$, it is also not equilibrated with respect to $a\left(\mathrm{SiO}_{2}\right)$. Furthermore, rapid cooling accompanying lava emplacements may contribute to nucleate $\mathrm{Si}$-grains by condensation of gaseous $\mathrm{SiO}$.

Eruptive processes implying adiabatic decompression may give rise to $\mathrm{SiC}$ formation by a similar mechanism, which may explain moissanite finds in volcanic breccia (Bauer et al., 1963) and rocks (Di Pierro et al., 2003) as well as in mantle xenoliths from subduction-related settings (Ishimaru et al., 2009). Intrusion of mafic magma into carbonaceous rocks in Siberian Traps or at the famous Disko Island are also remarkable field occurrences of SiC (Kitaynik, 1958; Oleinikov et al., 1977; Ryabov et al., 2010; Iacono-Marziano et al., 2012a); but the latter implies a bulk equilibrium (with all the extrusive rocks being equilibrated with oxygen fugacity as low as IW-4). In contrast, the occurrence of $\mathrm{SiC}$ as described in the literature of mantle rocks most likely involves local equilibrium operating during the emplacement of magmatic rocks at low pressure.

\section{Conclusion}

Redox buffering by carbon upon decompression to atmospheric pressure triggers extremely reducing conditions that can explain the sporadic but enigmatic occurrence of oxygendepleted phases such as $\mathrm{SiC}, \mathrm{Fe}$, or even $\mathrm{Si}$ in igneous rocks that are observed in very different geodynamic settings. This avoids calling upon excessively reducing mantle regions that are otherwise unexpected in existing models of mantle redox state. This process is operating as carbon is remaining in the system but is also consuming carbon, implying that the reduction reaction is stopped as $\mathrm{C}$ is exhausted. At low pressure we can expect $f \mathrm{O}_{2}$ as low as IW-6 in such C-saturated systems, whether molten or not, because carbon buffering would impose such low $f_{2}$ whatever the coexisting phases (melt or minerals). Redox buffering by carbon at low pressure is a potentially important mechanism in rock-forming processes, including heating and melting of chondrites, which has been poorly considered so far.

Acknowledgements: We acknowledge the comments by E. Mathez and anonymous reviewers on an earlier version of the paper. This work was partially supported by the European Research Council (agreement number 279790).

\section{References}

Bali, E., Audetat, A., Keppler, H. (2013): Water and hydrogen are immiscible in Earth's mantle. Nature, 495, 220-222.

Bauer, J., Fiala, J., Hrichova, R. (1963): Natural $\alpha$-silicon carbide. Amer. Mineral., 48, 620-634.
Behrens, H. \& Gaillard, F. (2006): Geochemical aspects of melts: volatiles and redox behavior. Elements, 2, 275-280.

Blumenthal, J.L., Santy, M.L., Burns, E.A. (1966): Kinetic studies of high-temperature carbon-silica reactions in charred silica-reinforced phenolic resins. AIAA J., 4(6), 1053-1057.

Bobrievich, A.P., Kalyuzhnii, V.A., Smirnov, G.I. (1957): Moissanite in the kimberlites of the East Siberian platform. Doklady AN SSSR, 115(6), 1189-1192.

Canil D. (2002): Vanadium in peridotites, mantle redox and tectonic environments: Archean to present. Earth Planet Sci. Lett., 195, 75-90.

Derkachenko, L.I., Zaretskaya, G.M., Obuhov, A.P., Sokolova, T.V., Filonenko, N.E. (1972): Mineralogy of silicon carbide (silicon carbide in industrial and natural rocks). Nauka, Leningrad.

Di Pierro, S., Gnos, E., Grobety, B.H., Armbruster, T., Bernasconi, S.M., Ulmer, P. (2003): Rock-forming moissanite (natural ?silicon carbide). Am. Mineral., 88, 1817-1821.

Frost, D.J. \& McCammon, C.A. (2008): The redox state of Earth's Mantle. Ann. Rev. Earth Planet. Sci., 36, 389-420.

Gaillard, F. \& Scaillet, B. (2009): The sulfur content of volcanic gases on Mars. Earth Planet. Sci. Lett., 279, 34-43.

Gaillard, F., Schmidt, B.C., Mackwell, S., McCammon, C. (2003): Rate of hydrogen-iron redox exchange in silicate melts and glasses. Geochim. Cosmochim. Acta, 67, 2427-2441.

Glushkina, S.E., Itsikson, G.V., Lovi, B.I. (1963): Moissanite in carbonatite deposit. Zap. Vsez. Min. Ob-Va., 92(6), 716-718.

Gnoevaja, N. \& Grozdanov, L. (1965): Moissanite from Triassic rocks, NW Bulgaria. Proc. Bulgarian Geol. Soc., 26, 89-95.

Gorshkov, A.I., Seliverstov, V.A., Sivtsov, A.V. (1995): Crystal chemistry and mineralogy of moissanite from alkali-ultrabasic volcanic complex (Kamchatka). Geol. Ore Depos., 37, 313-321.

Herzberg, C., Condie, K., Korenaga, J. (2010): Therma history of the Earth and its petrological expression. Earth Planet. Sci. Lett., 292, 79-88.

Iacono-Marziano, G., Morizet, Y., Le-Trong, E., Gaillard, F. (2012a): New experimental data and semi-empirical parameterization of $\mathrm{H}_{2} \mathrm{O}-\mathrm{CO}_{2}$ solubility in mafic melts. Geochim. Cosmochim. Acta, 97, 1-23.

Iacono-Marziano, G., Gaillard, F., Scaillet, B., Marecal, V., Pirre, M., Polozov, A.G., Arndt, N.T. (2012b): Extremely reducing conditions reached during basaltic intrusion in organic matterbearing sediments. Earth Planet. Sci. Lett., 357, 319-326.

Ishimaru, S., Arai, S., Shukuno, H. (2009): Metal-saturated peridotite in the mantle wedge inferred from metal-bearing peridotite xenoliths from Avacha volcano, Kamchatka. Earth Planet. Sci. Lett., 284, 352-360.

Jaques, A.L., Hall, A.E., Sheraton, J.W., Smith, C.B., Sun, S.S., Drew, R.M., Foudoulis, C., Ellingsen, K. (1989): Composition of crystalline inclusions and C-isotope composition of Argyle and Ellendale diamonds. in: "Kimberlites and related rocks", Ross, J., Jaques, A.L., Ferguson, J., Green, D.H., O'Reilly, S.Y., Danchin, R.V., Janse, A.J.A., eds., 2, p. 966-989. Blackwell Scientific, Cambridge, England.

Kaminsky, F.V., Bukin, V.I., Potapov, S.V., Arkus, N.G., Ivanova, V.G. (1968): Discoveries of silicon carbide under natural conditions and their genetic importance. AN SSSR Izvestiya, Ser. Geologicheskaya, 6, 57-66. English translation: Int. Geol. Rev. 1968, 11, 561-569.

Kitaynik A.F. (1958): Moissanite from the traps of the Siberian platform. in "Geology and ore deposits of Eastern Siberia" Iss. 3(24), Irkutsk. 
Klein-BenDavid, O., Izraeli, E.Z., Hauri, E., Navon, O. (2007): Fluid inclusions in diamonds from the Diavik mine, Canada and the evolution of diamond-forming fluids. Geochim. Cosmochim. Acta, 71, 723-744.

Klinger, N., Strauss, E.L., Komarek, K.L. (1966): Reactions between silica and graphite. J. Amer. Ceram. Soc., 49(7), 369-375.

Knippenberg W.F. (1963): Growth phenomena in silicon carbide. Philips Res. Rep., 18, 161-274.

Kopylova, M.G., Matveev, S., Raudsepp, M. (2007): Searching for parental kimberlite melt. Geochim. Cosmochim. Acta, 71, 3616-3629.

Kubaschewski O. (1982): Iron binary phase diagrams. SpringerVerlag, New-York.

Lee, J.-G., Cutler, I.B. (1975): Formation of silicon carbide from rice hulls. Am. Ceramic Soc. Bulletin, 54(2), 195-198.

Leung, I.S., Guo, W., Freidman, I., Gleason, J. (1990): Natural occurrence of silicon carbide in a diamondiferous kimberlite from Fuxian. Nature, 346, 352-354.

Leung, I.S., Taylor, L.A., Tsao, C.S., Han, Z. (1996): SiC in diamond and kimberlites: implications for nucleation and growth of diamond. Int. Geol Rev., 38, 595-606.

Luth R.W. (2009): The activity of silica in kimberlites, revisited. Contrib. Mineral. Petrol., 158, 283-294.

Lyakhovich V.V. (1967): Accessory minerals in granitoids of Soviet Union. Nedra Press, Moscow.

- (1979): Origin of accessory moissanite. AN SSSR Izvestiya, Ser. Geologicheskaya, 4, 63-74. (English translation: Int Geol Rev (1980) 22, 961-970).

Marshintsev, V.K. (1990): Natural silicon carbide in Yakutian kimberlites. Mineralogicheskii Zhurnal, 12, 17-26.

Marshintsev, V.K., Shchelchkova, S.G., Zol'nikov, G.V., Voskresenskaya, V.B. (1967): New data on moissanite from the Yakutian kimberlites. Geologiya i Geofizika, 12, 22-31.

Mathez, E.A., Fogel, R.A., Hutcheon, I.D., Marshintsev, V.K. (1995): Carbon isotopic composition and origin of SiC from kimberlites of Yakutia, Russia. Geochim. Cosmochim. Acta, 59, 781-791.

Mazzoni, A.D. \& Aglietti, E.F. (1997a): Carbonitriding of andalusite: phases involved and reaction mechanism. Materials Chem. Phys., 49, 196-203.

—, - (1997b): Mechanism of carbonitriding reactions of $\mathrm{SiO}_{2}-$ $\mathrm{Al}_{2} \mathrm{O}_{3}$ minerals in the Si-Al-O-N system. Appl. Clay Sci., 12, 447-461.

Mazzoni, A.D., Aglietti, E.F., Pereira, E. (1992): Phases and kinetics of beta-sialon formation from clays. Materials Lett., 14, 37-42.

McCammon, C. \& Kopylova, M.G. (2004): A redox profile of the Slave mantle and oxygen fugacity control in the cratonic mantle. Contrib. Mineral. Petrol., 148, 55-68.

Mendybaev, R.A., Beckett, J.R., Grossman, L., Stolper, E., Cooper, R.F., Bradley, J.P. (2002): Volatilization kinetics of silicon carbide in reducing gases: an experimental study with applications to the survival of presolar grains in the solar nebula. Geochim. Cosmochim. Acta, 66, 661-682.

Mineyeva, I.G. \& Kartenko, N.F. (1967): A discovery of moissanite in the contact aureole of an intrusion of alkaline and nepheline syenites. Zap. Vses Miner. Obsh., 96(3), 315-320.

Miyano, S., Sueno, S., Ohmasa, M., Fujii, T. (1982): A new SiC polytype, 45Rb. Acta Cryst., A 38, 477-482.

Moore, R.O., Gurney, J.J. (1989): Mineral inclusions in diamond from the Monastery kimberlite, South Africa. in: "Kimberlites and related rocks", Ross, J., Jaques, A.L., Ferguson, J., Green,
D.H., O’Reilly, S.Y., Danchin, R.V., Janse, A.J.A., eds., 2, p. 966-989. Blackwell Scientific, Cambridge, England.

Morizet, Y., Paris, M., Gaillard, F., Scaillet, B. (2010): C-O-H fluid solubility in haplobasalt under reducing conditions: an experimental study. Chem. Geol., 279, 1-16.

Nicholis, M.G. \& Rutherford, M.J. (2009): Graphite oxidation in the Apollo 17 orange glass magma: Implications for the generation of a lunar volcanic gas phase. Geochim. Cosmochim. Acta, 73, 5905-5917.

Oleinikov, B.V., Okrugin, A.V., Tomshin, M.V., Brovkin, A.A. (1977 ): Moissanite in trapps of Siberian platform. in "Geology and ore deposits of Yakutia", Bulletin, Yakutsk, 20-23.

Presser, V. \& Nickel, K.G. (2008): Silica on silicon carbide. Crit. Rev. Solid State Mater. Sci., 33, 1-99.

Rohrbach, A., Ballhaus, C., Golla-Schindler, U., Ulmer, P., Kamenetsky, V.S., Kuzmin, D.V. (2007): Metal saturation in the upper mantle. Nature, 449, 456-458.

Ryabov, V.V. \& Lapkovsky, A.A. (2010): Native iron (-platinum) ores from the Siberian Platform trap intrusions. Austral. J. Earth Sci., 57, 707-736.

Sato M. (1978): Oxygen fugacity of basaltic magmas and the role of gas-forming elements. Geophys. Res. Lett., 5, 447-449.

Shi, P.F. \& Saxena, S.K. (1992): Thermodynamic modelling of the C-H-O-S fluid system. Am. Mineral., 77, 1038-1049.

Shiryaev, A.A., Griffin, W.L., Stoyanov, E., Kagi, H. (2008): Natural silicon carbide from different geological settings: polytypes, trace elements, inclusions. 9th Int. Kimberlite Conf., Frankfurt, Ext abstr 9IKC-A-00075 (http://www.cosis.net/ abstracts/9IKC/00075/9IKC-A-00075-1.pdf).

Shiryaev, A.A., Griffin, W.L., Stoyanov, E. (2011): Moissanite (SiC) from kimberlites: polytypes, trace elements, inclusions and speculations on origin. Lithos, 122, 152-164.

Stagno, V., Ojwang, D.O., McCammon, C.A., Frost, D.J. (2013): The oxidation state of the mantle and the extraction of carbon from Earth's interior. Nature, 493(7430), 84-88.

Symonds, R.B. and Reed, M.H. (1993): Calculation of multicomponent chemical equilibria in gas-solid-liquid systems: Calculation methods, thermochemical data and applications to studies of high-temperature volcanic gases with examples from Mount St. Helens: Amer. J. Sci., 293, 758-864.

Trumbull, R.B., Yang, J.S., Robinson, P.T., Di Pierro, S., Vennemann, T., Wiedenbeck, M. (2009): The carbon isotope composition of natural SiC (moissanite) from the Earth's mantle: new discoveries from ophiolites. Lithos, 113, 612-620.

Ulmer, G.C., Grandstaff, D.E., Woermann, E., Gobbels, M., Schonitz, M., Woodland, A.B. (1998): The redox stability of moissanite ( $\mathrm{SiC}$ ) compared with metal-metal oxide buffers at $1773 \mathrm{~K}$ and at pressures up to $90 \mathrm{kbar}$. N. Jb. Mineral. Abh., 172, 279-307.

Woodland, A.B. \& Koch, M. (2003): Variation in oxygen fugacity with depth in the upper mantle beneath the Kaapvaal craton, Southern Africa. Earth Planet Sci. Lett., 24, 295-310.

Xu, S., Wu, W., Xiao, W., Yang, J., Chen, J., Ji, S. (2008): Moissanite in serpentinite from the Dabie mountain in China. Mineral. Mag., 72, 899-908.

Received 21 March 2013

Modified version received 11 July 2013

Accepted 29 August 2013 